\title{
Pediatric claims in Italy during a 8-years survey
}

\author{
Rino Agostiniani, Antonio Correra, Paolo D’Agostino, Ernesto D’Aloja, Luigi Greco, Paolo Tagliabue, Vassilios Fanos*, \\ The Risk Management Commission of the Italian Society of Pediatrics
}

From 70th Congress of the Italian Society of Pediatrics, Joint National Meeting SIP, SICuPP, SITIP

Palermo, Italy. 11-14 June 2014

Very few data are available on pediatrics malpractice claims. We report the first data obtained in Italy on pediatrics regarding a wide population study during a 8 years survey. Data concerning 164 claims are presented and discussed. Our data suggest how big is the problem and they may be helpful to face it.

\section{Introduction}

Pediatrics is not a high-risk specialty in terms of the number of claims, although some of the largest financial payouts have been for multiple disabled children with perinatal injuries and long life expectancy [1-5]. We report the first data obtained in Italy on pediatrics regarding a wide population study.

\section{Materials and methods}

We conducted a retrospective, descriptive analysis of a nation-wide database on pediatric malpractice claims, in which patients alleged a permanent impairment related to a medical misconduct. The Italian Society of Pediatrics (Società Italiana di Pediatria; SIP) has developed a link thorough insurance broker Willis Italian SpA - with an insurance company (CARIGE Assicurazioni SpA) that insures a wide proportion of Italian pediatricians (nearly $60 \%$ out of 8000 physicians).

We asked Willis to perform a query of its database, looking at malpractice claims reported between January, $1^{\text {st }} 2005$ and December, $31^{\text {st }} 2012$ involving pediatrics while avoiding neonatology.

Definitions are used as previously reported by ours [6].

\section{Results}

We found 164 claims, the majority of which were reported in the last two years (year 2011: $n=65$; year 2012: $n=35$ ), covering more than $2 / 3$ of the total number of claims. 89 were from South Italy, 43 form the north and 32 from Central Italy. 141 involved the public health system, 13 the private health system and 8 family pediatricians. 102 were criminal actions, 53 civil actions, 5 mixed actions and 4 cautelative claims. We found 89 death claims and 65 claims for permanent impairment. Each claim interested one or more physicians. Main areas of class are presented in table 1. Among surgical pathologies, 6 were gastrointestinal and 6 involved testis. Among infections, 6 were pleura-pulmonary diseases, 5 fulminant sepsis ( 2 meningococcal), 3 tuberculosis (2 meningeal, 1 pulmonary), 1 Salmonellosis, 1 Candidosis, 1 chicken pox, 1 scarlet fever.

\section{Conclusions}

Malpractice data can be used to identify problem-prone clinical processes and suggest interventions that may reduce errors. Continual medical education should be oriented in areas of claims also improving physician communication skills [7].

Table 1 Main area of claims in the 8 years-survey

\begin{tabular}{lc}
\hline Main area of claims & $\begin{array}{c}\text { Number of } \\
\text { claims }\end{array}$ \\
\hline Surgical pathology & 26 \\
\hline Infections & 20 \\
\hline $\begin{array}{l}\text { Gastrointestinal medical problem (vomiting, diarrhea) } \\
\text { with subsequent dehydration }\end{array}$ & 14 \\
\hline latrogenic pathology (drugs, catheters...) & 5 \\
\hline Undiagnosed tumor & 4 \\
\hline Undiagnosed congenital cardiopathy & 3 \\
\hline Post vaccinal encephalitis & 3 \\
\hline Undiagnosed urinary disease & 2 \\
\hline Undiagnosed rare disease & 2 \\
\hline Undiagnosed deafness & 2 \\
\hline
\end{tabular}




\section{References}

1. Marcovitch H: When are paediatricians negligent? Arch Dis Child 2011, 96:117-120.

2. Selbst SM, Friedman MJ, Singh SB: Epidemiology and etiology of malpractice lawsuits involving children in US emergency departments and urgent care centers. Pediatr Emerg Care 2005, 21:165-169.

3. Kain ZN, Caldwell-Andrews AA: What pediatricians should know about child-related malpractice payments in the United States. Pediatrics 2006, 118:464-468.

4. Carroll $A E$, Buddenbaum JL: Malpractice claims involving pediatricians: Epidemiology and etiology. Pediatrics 2007, 120:933-935.

5. Ozdemir MH, Ergönen TA, Can IO: Medical malpractice claims involving children. Forensic Sci Int 2009, 191:80-85.

6. Tagliabue P, Greco L, Agostiniani R, Carbone MT, D'Agostino P, Correra A: Neonatal malpractice claims in Italy: how big is the problem and which are the causes? J Matern Fetal Neonatal Med 2012, 25:493-7, doi: 10.3109/ 14767058.2011.622004.

7. D'Aloja E, Floris L, Muller M, Birocchi F, Fanos V, Paribello F, Demontis R: Shared decision-making in neonatology: An utopia or an obtainable goal? J Matern Fetal Neonatal Med 2010, 23(Suppl 3):56-58.

doi:10.1186/1824-7288-40-S1-A87

Cite this article as: Agostiniani et al: Pediatric claims in Italy during a 8-years survey. Italian Journal of Pediatrics 2014 40(Suppl 1):A87.

\section{Submit your next manuscript to BioMed Central} and take full advantage of:

- Convenient online submission

- Thorough peer review

- No space constraints or color figure charges

- Immediate publication on acceptance

- Inclusion in PubMed, CAS, Scopus and Google Scholar

- Research which is freely available for redistribution

Submit your manuscript at www.biomedcentral.com/submit 